\title{
Agrochemical modeling in rivers: the Sampaio irrigation project case study
}

\author{
G. C. Nascimento ${ }^{1}$ \& A. M. Pereira Andreazza ${ }^{2}$ \\ ${ }^{1}$ Hydrosphera Engenharia Ambiental Ltd., Brazil \\ ${ }^{2}$ Indpendent Consultant, Brazil
}

\begin{abstract}
This study evaluates the agrochemical impact present in irrigation effluents of the surrounding hydric environment. The case studied refers to the Sampaio Irrigation Project, located at the far north of Tocantins State, on the left margin of the Tocantins River, in which case this river is the receiving body of polder drainage intended for a rice culture using flood irrigation. By using mathematical modeling, three distinct hydrological scenarios were simulated, aiming to identify concentrations of the chemical compounds used in the Tocantins River, and the range of the impacted area, adopted as the area under direct influence of this impact. We concluded that only the compound Carbaryl had higher concentrations than the limitations allowed for the Tocantins River by CONAMA [National Environmental Council] Resolution No. 357/2005 for class 1 and class 2 rivers, and that the extension of the area affected by such concentrations is of about $6 \mathrm{~km}$ [3.73 miles]. Having obtained these results from our model, specific measures were recommended to prevent the identified impact, and added to the Environmental Impact Study and Environmental Impact Report (EIA/RIMA) for the project.
\end{abstract}

Keywords: environmental impact, agrochemical composts, toxic substances modeling in water.

\section{Introduction}

The drainage of agricultural areas often introduces strong environmental impacts in surrounding areas as it carries part of the agrochemical substances applied to crops to natural water resources. These impacts are an object of concern all over 
the world, and although efforts are being made to reduce the use of agrochemical substances by means of new and restrictive laws, they are widely used in modern agricultural practice.

Mathematical modeling is an important tool to assess environmental impact of these substances in the water column in order to evaluate their dispersion and to select the substances that cause the least problems.

\section{The Sampaio irrigation project}

\subsection{General features}

The Sampaio project is an irrigation perimeter of 1.071 ha area in the towns of Sampaio, Carrasco Bonito and Augustinópolis. Part of this area (142 ha) is used to grow fruits, the remaining area receives crops of rice, corn and soy beans (929 ha) and is situated in a polder near the left bank of the Tocantins river.

The Tocantins river is a tributary of the lower basin of the Amazon river and its mean annual flow is $8.136,8 \mathrm{~m}^{3} / \mathrm{s}$. It provides the source of water for irrigation and also receives the drainage of the rice crops.

The project is constituted of: a protection dam against Tocantins river floods, main channel, pumping station, distribution channels, pressurizing station, drainage channels, drainage pumping station, energy supply system, and road system.

\subsection{Agrochemical compounds design}

As the tropical environment is aggressive to crops, some agrochemicals compounds were recommended in the agronomic project, in particular for their use in rice crops, which will be flooded, and for this reason generate almost all of the drainage water. The proposed substances that could reach the Tocantins river were: Carbaryl, Carbofuran, Cyfluthrin, Diazinon, Dibrom, Esfenvalerate, Fenitrothion, Lambda $(\lambda)$ cyhalothrin, Malathion and Permethrin.

\section{Mathematical modeling of toxic substances}

\subsection{Agrochemicals: characteristics and environmental fate}

Table 1 shows the maim characteristics of the agrochemicals that are employed in the rice crops. Table 2 presents the environmental fate of each agrochemical modeled and Table 3 shows the level of significance of each substance. From these tables it can be seen that the majority of the products associate to particles, and for some products that remain in the water column, such as Carbaryl, Carbofuran and Malathion, the mass transference and degradation processes are relevant features.

Table 5 presents the main physical and chemical rates and constants of modeled agrochemicals. 
Table 1: $\quad$ Main characteristics of the agrochemicals employed.

\begin{tabular}{|l|c|c|}
\hline \multicolumn{1}{|c|}{ Substance } & Application rates & Limits $^{(*)}$ \\
\hline Carbaryl & $960 \mathrm{a} 1.110 \mathrm{~g} / \mathrm{ha}$ & $0,02 \mu \mathrm{g} / \mathrm{L}$ \\
\hline Carbofuran & $450 \mathrm{a} 500 \mathrm{~g} / \mathrm{ha}$ & $<10 \mu \mathrm{g} / \mathrm{L}$ Paration \\
\hline Cyfluthrin & $7,5 \mathrm{a} 10 \mathrm{~g} / \mathrm{ha}$ & - \\
\hline Diazinon & $0,25 \mathrm{a} 0,5 \mathrm{~kg} / \mathrm{ha}$ & $<10 \mu \mathrm{g} / \mathrm{L}$ Paration \\
\hline Dibrom & $0,25 \mathrm{a} 0,5 \mathrm{~kg} / \mathrm{ha}$ & - \\
\hline Esfenvalerate & - & - \\
\hline Fenitrothion & - & - \\
\hline$\lambda$ cyhalothrin & $270 \mathrm{~g} / \mathrm{ha}$ & $<10 \mu \mathrm{g} / \mathrm{L}$ Paration \\
\hline Malathion & - & - \\
\hline Permethrin & $0,8 \mathrm{a} 2,0 \mathrm{~L} / \mathrm{ha}$ & $<10 \mu \mathrm{g} / \mathrm{L}$ Paration \\
\hline
\end{tabular}

(*) Brazilian law: Resolução do CONAMA 357/2005.

Table 2: $\quad$ Environmental fate of the agrochemicals employed.

\begin{tabular}{|c|c|c|c|}
\hline Substance & Air & Soil & Water \\
\hline Carbaryl & $\begin{array}{l}\text { Particulate phase and } \\
\text { vapor }\end{array}$ & $\begin{array}{l}\text { Moderate } \\
\text { mobility }\end{array}$ & $\begin{array}{l}\text { Remains is water } \\
\text { column }\end{array}$ \\
\hline Carbofuran & $\begin{array}{l}\text { Particulate phase and } \\
\text { vapor }\end{array}$ & High mobility & $\begin{array}{c}\text { Remains is } \\
\text { water column }\end{array}$ \\
\hline Cyfluthrin & $\begin{array}{c}\text { No volatilization, } \\
\text { remains associated to } \\
\text { particles }\end{array}$ & $\begin{array}{l}\text { Adsorb to soil, } \\
\text { shows some } \\
\text { mobility }\end{array}$ & $\begin{array}{c}\text { Adsorb to } \\
\text { suspended particles }\end{array}$ \\
\hline Diazinon & $\begin{array}{l}\text { Particulate phase and } \\
\text { vapor }\end{array}$ & $\begin{array}{c}\text { Low to Moderate } \\
\text { mobility }\end{array}$ & $\begin{array}{c}\text { Adsorb to } \\
\text { suspended particles }\end{array}$ \\
\hline Dibrom & Associate to particles & Low mobility & $\begin{array}{c}\text { Adsorb to } \\
\text { suspended particles }\end{array}$ \\
\hline Esfenvalerate & $\begin{array}{l}\text { Particulate phase and } \\
\text { vapor }\end{array}$ & $\begin{array}{l}\text { Very low } \\
\text { mobility. No } \\
\text { lichiviation } \\
\end{array}$ & $\begin{array}{c}\text { Adsorb to } \\
\text { suspended particles }\end{array}$ \\
\hline Fenitrothion & $\begin{array}{l}\text { Particulate phase and } \\
\text { vapor }\end{array}$ & $\begin{array}{l}\text { Low to Moderate } \\
\text { mobility }\end{array}$ & $\begin{array}{l}\text { Low adsorption to } \\
\text { suspended particles }\end{array}$ \\
\hline$\lambda$ cyhalothrin & $\begin{array}{c}\text { No volatilization, } \\
\text { remains associated to } \\
\text { particles }\end{array}$ & $\begin{array}{l}\text { Adsorb to soil, } \\
\text { shows no } \\
\text { mobility } \\
\end{array}$ & $\begin{array}{c}\text { Adsorb to } \\
\text { suspended particles }\end{array}$ \\
\hline Malathion & Vapor only & $\begin{array}{l}\text { Very high } \\
\text { mobility }\end{array}$ & $\begin{array}{l}\text { Remains is water } \\
\text { column }\end{array}$ \\
\hline Permethrin & $\begin{array}{c}\text { Particulate phase and } \\
\text { vapor }\end{array}$ & $\begin{array}{l}\text { Adsorb to soil, } \\
\text { shows no } \\
\text { mobility } \\
\end{array}$ & $\begin{array}{c}\text { Adsorb to } \\
\text { suspended particles }\end{array}$ \\
\hline Thriclorfon & $\begin{array}{l}\text { Particulate phase and } \\
\text { vapor }\end{array}$ & $\begin{array}{l}\text { Very high to high } \\
\text { mobility }\end{array}$ & $\begin{array}{l}\text { Remains is water } \\
\text { column }\end{array}$ \\
\hline
\end{tabular}


Table 3: Level of significance of the main degradation factors in water for the studied substances.

\begin{tabular}{|l|c|c|c|c|c|}
\hline \multicolumn{1}{|c|}{ Substance } & Biodegradation & Volatilization & Photolysis & Hydrolysis & $\begin{array}{c}\text { Bio- } \\
\text { accumulation }\end{array}$ \\
\hline Carbaryl & V I & L & I & I* & L \\
\hline Carbofuran & I & I & I & I & L \\
\hline Cyfluthrin & I & VI & VI & VL & H \\
\hline Diazinon & I & ND & VI & VL & M to H \\
\hline Dibrom & CD & L & S & S (pH=7) & L \\
\hline Esfenvalerate & ND & I & I & I & H \\
\hline Fenitrothion & I & L & VI & VI** & M to L \\
\hline$\lambda$ cyhalothrin & I & VI & VI & VI *** & M*** \\
\hline Malathion & VI & L & I & VL* & L \\
\hline Permethrin & I & I & I & VL* & H \\
\hline Thriclorfon & I & VL & L & Variable & L \\
\hline
\end{tabular}

CD - Conflicting data, ND - No data available, L - Low, VL - Very low, $\mathrm{M}-$ medium, $\mathrm{H}$ - high, $\mathrm{I}-$ important, $\mathrm{VI}-$ Very important, $\mathrm{S}-$ sable. *increases with $\mathrm{pH}$.

** decreases with $\mathrm{pH}$.

$* * *$ decreases in presence of fulvic acids.

Table 4: $\quad$ Scenarios for modeling.

\begin{tabular}{|c|c|c|c|c|}
\hline \multicolumn{2}{|c|}{ Flow $\left(\mathrm{m}^{3} / \mathrm{s}\right)$} & \multirow[b]{2}{*}{ Occurrence } & \multirow{2}{*}{$\begin{array}{l}\text { Water } \\
\text { height } \\
(\mathrm{m})\end{array}$} & \multirow{2}{*}{$\begin{array}{l}\text { Time after } \\
\text { application } \\
\text { (d) }\end{array}$} \\
\hline $\begin{array}{l}\text { Drainage } \\
\text { effluent }\end{array}$ & $\begin{array}{l}\text { Tocantins } \\
\text { river }\end{array}$ & & & \\
\hline 1,26 & 3.503 & No rain. Drain by gravity & 0,1 & 2 \\
\hline 0,40 & 2.760 & During medium rain & 0,2 & 1 \\
\hline 6,40 & 8.137 & $\begin{array}{l}\text { Heavy storms, maximum } \\
\text { pumping }\end{array}$ & 0,2 & 2 \\
\hline
\end{tabular}

\subsection{Scenarios}

The scenarios modeled were based on the following assumptions:

1. The compounds must stay in contact with the culture for at least 48 hours;

2. The flooded areas act as fully mixed reactors;

3. The water column height in flooded rice is $10 \mathrm{~cm}$, producing a total volume of $9.310^{5} \mathrm{~m}^{3}$;

4. In case of strong showers the maximum water column is $20 \mathrm{~cm}$, in order to avoid drowning of the rice plants;

5. Agrochemicals are not applied simultaneously, it was assumed that $10 \%$ of the area is affected by the compounds studied.

6. Rice cultures grow from December to March when it is harvested. 
Water Pollution IX 365

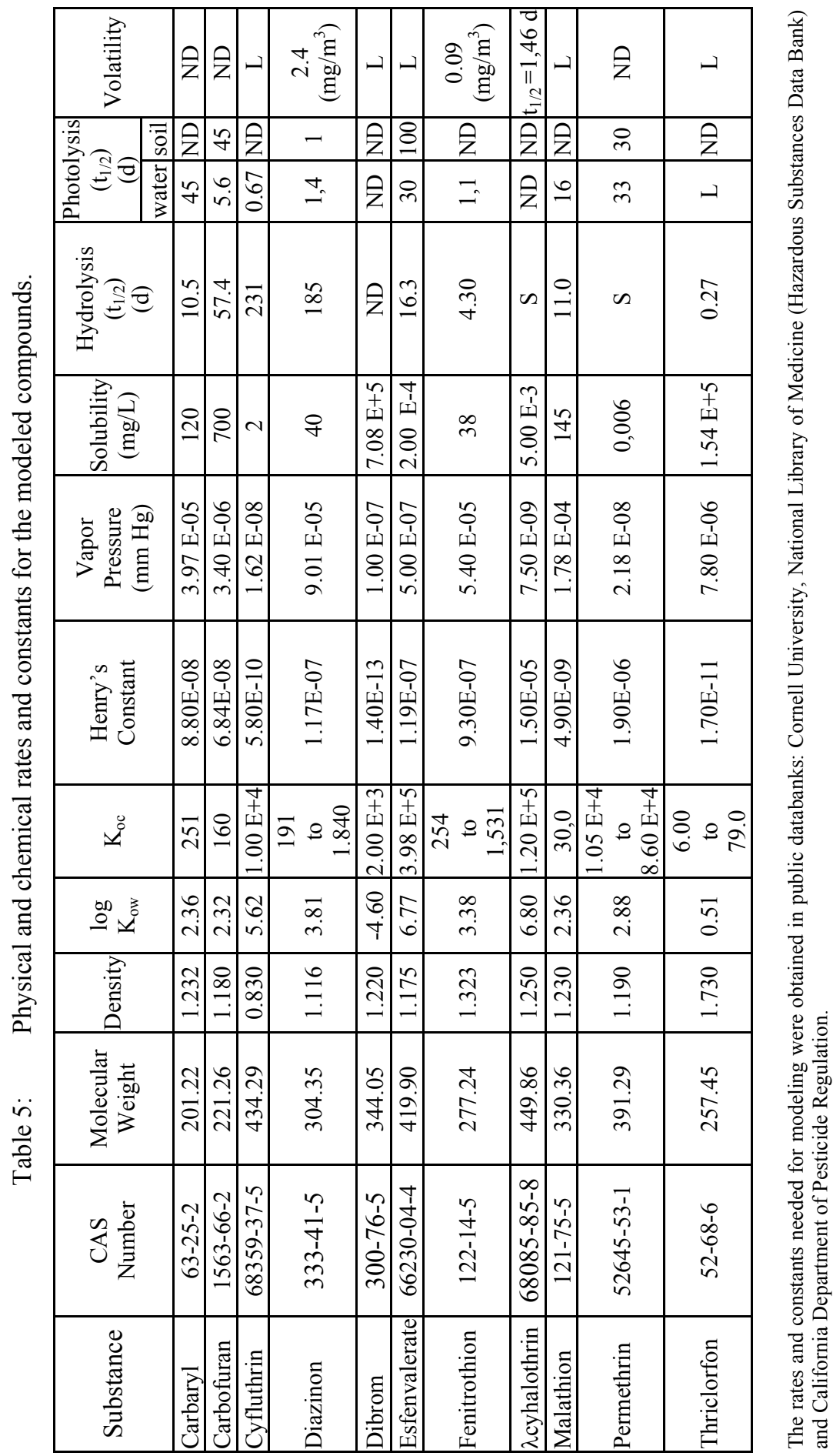

WIT Transactions on Ecology and the Environment, Vol 111, (C) 2008 WIT Press www.witpress.com, ISSN 1743-3541 (on-line) 


\subsection{Equations}

For steady state CHAPRA [1] presents the following mass balance for solids:

(a) aquatic phase

$$
-U \frac{d m_{1}}{d x}-\frac{v_{s}}{H_{1}} m_{1}+\frac{v_{r}}{H_{1}} m_{2}=0
$$

(b) solid phase

$$
v_{s} m_{1}-v_{r} m_{2}-v_{b} m_{2}=0
$$

where $\mathrm{U}$ is the river velocity; $\mathrm{m}_{1}$ is solid concentration in water; $\mathrm{m}_{2}$ is solid concentration in sediment layer, which can be written as porosity times density; $\mathrm{v}_{\mathrm{s}}$ is sedimentation velocity; $\mathrm{v}_{\mathrm{b}}$ is burial velocity; and $\mathrm{v}_{\mathrm{r}}$ is ressuspension velocity.

Equations (1) and (2) are solved for:

$$
m_{1}=m_{1}(0) e^{-\frac{v_{s}}{H_{1} U} x}+\frac{v_{r}(1-\phi) \rho}{v_{s}}\left(1-e^{-\frac{v_{s}}{H_{1} U} x}\right)
$$

where $\phi$ is porosity and $\rho$ is sediments specific weight.

If the initial concentration of solids $m_{1}(0)$ is low, the downstream concentration will approach steady state and will be given by:

$$
m_{1}(\infty)=\frac{v_{r}(1-\phi) \rho}{v_{s}}
$$

Using the previous results it is possible to make the constituent mass balance:

(a) aquatic phase

$$
-U \frac{d c_{1}}{d x}-k_{1} c_{1}-\frac{v_{v}}{H_{1}} F_{d 1} \cdot c_{1}-\frac{v_{s}}{H_{1}} F_{p 1} \cdot c_{1}+\frac{v_{d}}{H_{1}}\left(F_{d 2} \cdot c_{2}-F_{d 1} \cdot c_{1}\right)+\frac{v_{r}}{H_{1}} c_{2}=0
$$

(b) solid phase

$$
v_{s} \cdot F_{p 1} \cdot c_{1}+v_{d}\left(F_{d 1} \cdot c_{1}-F_{d 2} \cdot c 2\right)-k_{2} \cdot H_{2} \cdot c_{2}-v_{r} \cdot c_{2}-v_{b} \cdot c_{2}=0
$$

where $c_{1}$ is the concentration of constituent in water $(\mu \mathrm{g} / \mathrm{L}), c_{2}$ is the concentration of constituent in the sediment layer $(\mu \mathrm{g} / \mathrm{L}), \mathrm{k}_{1}$ is the first order decomposition rate in water and $\mathrm{k}_{2}$ is the first order decomposition rate in sediment, the $\mathrm{F}$ factors are the ratios of constituent in $\mathrm{d}$ - dissolved form, $\mathrm{p}$ particulate form and 1- aquatic phase and 2- solid phase.

$$
\begin{gathered}
F_{d 1}=\frac{1}{1+K_{d 1} m} \\
F_{p 1}=\frac{K_{d 1} m}{1+K_{d 1} m}
\end{gathered}
$$




$$
F_{d 2}=\frac{1}{\phi+K_{d 2}(1-\phi) \rho}
$$

If the initial concentration is $\mathrm{c}_{1}(0)$, differential equation (7) is solved for:

$$
c_{1}=R_{21} \cdot c_{1}(0) \cdot e^{-\frac{v_{T}}{H_{1} U} \cdot x}(10) \quad \text { and } c_{2}=R_{2,1} \cdot c_{1}
$$

where:

$$
\begin{gathered}
v_{T}=k_{1} \cdot H_{1}+v_{v} \cdot F_{d 1}+\left(v_{s} \cdot F_{p 1}+v_{d} \cdot F_{d 1}\right)\left(1-F_{r}^{\prime}\right) \\
R_{2,1}=\frac{v_{s} F_{p 1}+v_{d} F_{d 1}}{v_{d} F_{d 2}+k_{2} H_{2}+v_{r}+v_{b}} \\
F_{r}^{\prime}=\frac{v_{r}+v_{d} F_{d 2}}{v_{d} F_{d 2}+k_{2} H_{2}+v_{r}+v_{b}}
\end{gathered}
$$

\subsection{Mass transference mechanisms}

\subsubsection{Sorption}

In this process part of dissolved mass is transferred to solid phase. The ratio of transference $K_{d}$ can be evaluated from the carbon content in particulate $\left(f_{o c}\right)$ matter and from the partition coefficient for organic carbon $\left(\mathrm{K}_{\mathrm{oc}}\right)$, which is related to the water octanol partition coefficient $\left(\mathrm{K}_{\mathrm{ow}}\right)$, characteristic for each substance.

\subsubsection{Volatilization}

Volatilization is the mass transference from water or soil to air, leaving the system. It is accounted by the volatilization velocity $v_{v}$.

$$
v_{v}=K_{l} \frac{H_{e}}{H_{e}+R \cdot T_{a} \cdot\left(\frac{K_{l}}{K_{g}}\right)}
$$

with

$\mathrm{H}_{\mathrm{e}}$ is the Henry's Constant,

$\mathrm{T}_{\mathrm{a}}$ is temperature $(\mathrm{K})$

$\mathrm{R}$ is gas constant $\left(8,206 \times 10^{-5-} \mathrm{atm} . \mathrm{m}^{3} / \mathrm{K} / \mathrm{mol}\right)$

$K_{l}=K_{l, O_{2}}\left(\frac{32}{M}\right)^{0,25}$, is the mass transference coefficient to liquid

$K_{g}=168 \cdot U_{v} \cdot\left(\frac{18}{M}\right)^{0,25}$, is the mass transference coefficient to air

$\mathrm{M}$ is the molecular weight and $K_{l, O_{2}}$ is the mass transference coefficient of oxygen $(0.864 / \mathrm{d})$. 


\subsection{Degradation mechanisms}

\subsubsection{Photolysis}

Photolysis can be direct whereby the compound is directly degraded by light or indirect when intermediate compounds react with light.

\subsubsection{Hydrolysis}

Hydrolysis is the reaction in which the molecule bounds are broken to form new bounds with hydrogen and hydroxyl. These reactions are catalyzed by acids and bases, and to a lesser extent, by water.

\subsubsection{Biodegrading}

The compounds are transformed by microorganisms. The term refers to several mechanisms, such as mineralization, activation, cometabolism, detoxification and defusing.

All of these three mechanisms are accounted in the model by it's half life $\left(t_{1 / 2}\right)$, which is related to the degradation coefficient by: $t_{1 / 2}=\frac{0,6931}{k}, k$ being the degradation coefficient: photolysis $\left(K_{f}\right)$, hydrolysis $\left(K_{h}\right)$ or microorganisms $\left(K_{b}\right)$.

\section{Application and results}

Table 6 shows the values calculated using the data in Table 5, and equations (1)-(14).

Table 7 shows the initial value for concentrations in each scenario modeled. It can be seen that only Carbaryl exceeds the limits stated by Brazilian law for initial dilution in the Tocantins river.

Table 6: $\quad$ Calculated parameters.

\begin{tabular}{|c|c|c|c|c|c|c|c|}
\hline \multirow[t]{2}{*}{ Substance } & \multirow[t]{2}{*}{$\mathrm{K}_{\mathrm{ow}}$} & \multirow[t]{2}{*}{$\mathrm{K}_{\mathrm{d}}$} & \multicolumn{2}{|c|}{$\begin{array}{c}\mathrm{m}= \\
120(\mathrm{mg} / \mathrm{L})\end{array}$} & \multicolumn{3}{|c|}{ Volatilization } \\
\hline & & & $F_{d}$ & $F_{p}$ & $\mathrm{k}_{1}$ & $\mathrm{k}_{\mathrm{g}}$ & $v_{v}$ \\
\hline Carbaryl & $2.29 \mathrm{E}+02$ & $1.41 \mathrm{E}-04$ & 0.983 & 0.017 & 1.637 & 275.6 & 9.91E-04 \\
\hline Carbofuran & $2.09 \mathrm{E}+02$ & $1.29 \mathrm{E}-04$ & 0.985 & 0.015 & 1.598 & 269.2 & 7.53E-04 \\
\hline Cyfluthrin & $4.17 \mathrm{E}+05$ & $2.57 \mathrm{E}-01$ & 0.031 & 0.969 & 1.350 & 227.4 & 5.39E-06 \\
\hline Diazinon & $6.46 \mathrm{E}+03$ & $3.98 \mathrm{E}-03$ & 0.677 & 0.323 & 1.476 & 248.5 & $1.19 \mathrm{E}-03$ \\
\hline Dibrom & $2.51 \mathrm{E}-05$ & $1.55 \mathrm{E}-11$ & 1.000 & 0.000 & 1.431 & 241.0 & $1.38 \mathrm{E}-09$ \\
\hline Esfenvalerate & $5.89 \mathrm{E}+06$ & $3.63 \mathrm{E}+00$ & 0.002 & 0.998 & 1.362 & 229.3 & $1.12 \mathrm{E}-03$ \\
\hline Fenitrothion & $2.38 \mathrm{E}+03$ & $1.47 \mathrm{E}-03$ & 0.850 & 0.150 & 1.511 & 254.4 & 9.61E-03 \\
\hline$\lambda$ cyhalothrin & $6.31 \mathrm{E}+06$ & $3.89 \mathrm{E}+00$ & 0.002 & 0.998 & 1.339 & 225.4 & $1.25 \mathrm{E}-01$ \\
\hline Malathion & $2.29 \mathrm{E}+02$ & $1.41 \mathrm{E}-04$ & 0.983 & 0.017 & 1.446 & 243.5 & 4.88E-05 \\
\hline Permethrin & $7.59 \mathrm{E}+02$ & $4.68 \mathrm{E}-04$ & 0.947 & 0.053 & 1.386 & 233.4 & 1.79E-02 \\
\hline Thriclorfon & $3.24 \mathrm{E}+00$ & $2.00 \mathrm{E}-06$ & 1.000 & 0.000 & 1.539 & 259.2 & $1.80 \mathrm{E}-07$ \\
\hline
\end{tabular}




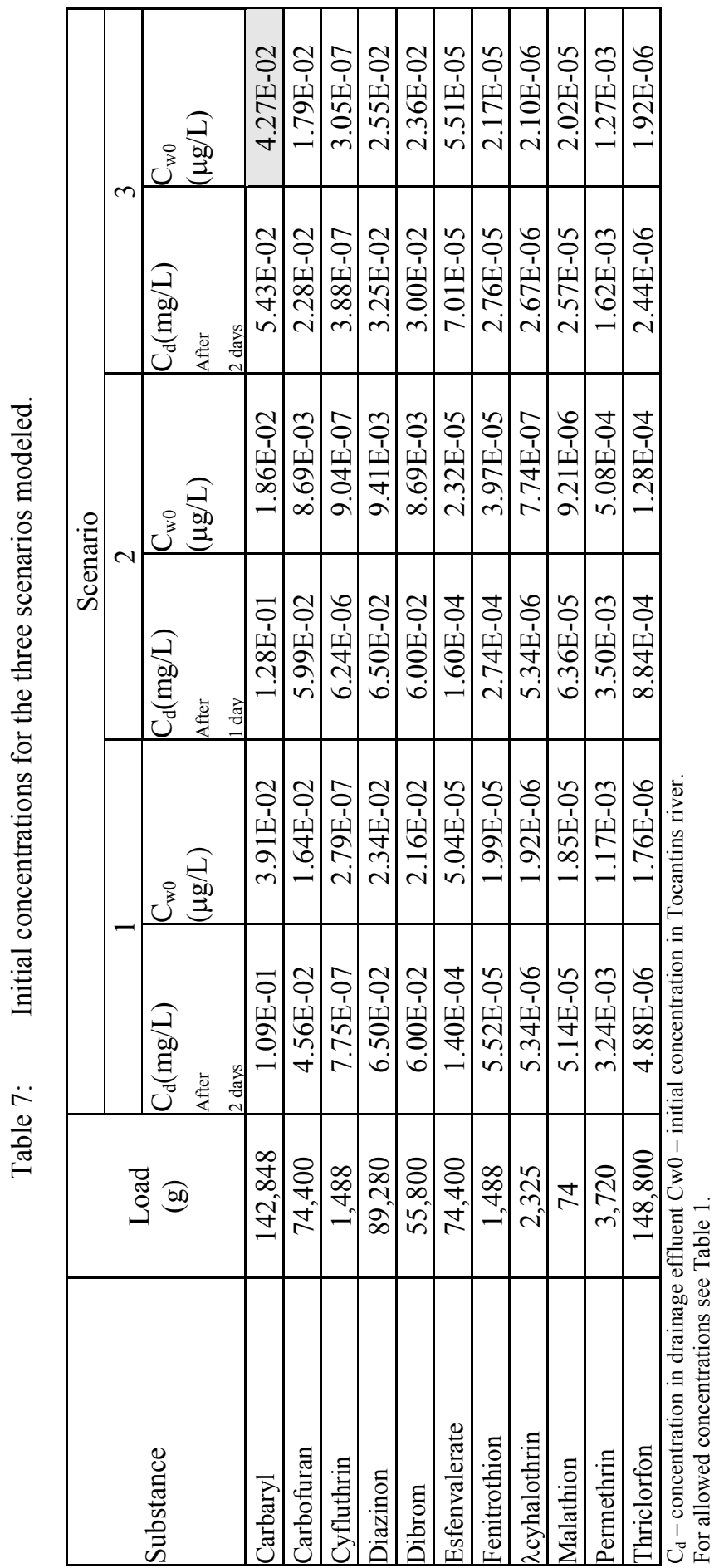


Considering equation (10) the initial concentration of $4.2710^{-2} \mu \mathrm{g} / \mathrm{L}$ for Carbaryl, and the limit of $210^{-2} \mu \mathrm{g} / \mathrm{L}$ stated by Brazilian legislation, the affected length of the Tocantins river can be calculated as:

where

$$
C=0,02=C_{o} \cdot e^{-\left(\frac{v_{T}}{H_{1}}+k_{h}+k_{b}+k_{f}\right) \cdot \frac{x}{U}}
$$

$$
\begin{aligned}
& v_{T}=k_{1} \cdot H_{1}+v_{v} \cdot F_{d 1}+\left(v_{s} \cdot F_{p 1}+v_{d} \cdot F_{d 1}\right)\left(1-F_{r}^{\prime}\right)= \\
& 0,052 * 10+9,1 \cdot 10^{-4} * 1+(0,25 * 0+0 * 1)(1-1)=0,521 \frac{m}{d} \\
& k_{h}+k_{b}+k_{f}=0,066+2,039+0,0154=2,641 \mathrm{~d}^{-1}
\end{aligned}
$$

and

$$
\begin{aligned}
& F_{d 1}=\frac{1}{1+K_{d 1} m}=\frac{1}{1+7,07^{-7,100}} \approx 1 \\
& F_{p 1}=\frac{K_{d 1} m}{1+K_{d 1} m}=\frac{7,07^{-7,100}}{1+7,07^{-7,100}} \approx 0
\end{aligned}
$$

$\mathrm{k}_{\mathrm{h}}$ is the hydrolysis rate $\left(\mathrm{t}_{1 / 2}=10,5 \mathrm{~d}->\mathrm{k}_{\mathrm{h}}=0,066\right)$

$\mathrm{k}_{\mathrm{b}}$ is the biodegrading rate $\left(\mathrm{t}_{1 / 2}=0,34 \mathrm{~d}->\mathrm{k}_{\mathrm{b}}=2,039\right)$

$\mathrm{k}_{\mathrm{f}}$ is the photolysis rate $\left(\mathrm{t}_{1 / 2}=45 \mathrm{~d}->\mathrm{k}_{\mathrm{f}}=0,0154\right)$

Considering the river velocity $(\mathrm{U})$ of $0.2 \mathrm{~m} / \mathrm{s}$ and the depth $\left(\mathrm{H}_{1}\right)$ of $10 \mathrm{~m}$, the length $\mathrm{x}$ affected will be $6.030 \mathrm{~m}$.

\section{Conclusions}

The environmental study concluded that if Carbaryl is applied to crops, the area must stay without drainage for at least 7 days in order to reach the Tocantins river within concentration limits. As a recommendation of the study it is proposed that this compound should be replaced by another type of pesticide or, if it is unavoidable, heavy storm periods must be avoided in order to prevent maximum pumping flow.

\section{References}

[1] CHAPRA, S. C. (1997). Surface Water-Quality Modeling. The McGrawHill Companies Inc., New York, 844 p.

[2] Department of Pesticide Regulation, California State, http://www.cdpr.ca.gov.

[3] Sistema de Agrotóxicos Fitossanitários (Agrofit) do Ministério da Agricultura, http://extranet.agricultura.gov.br/agrofit_cons/principal_agrofit_cons

[4] United States National Library of Medicine, National Institutes of Health, Toxicology Data Network - TOXNET, http://toxnet.nlm.nih.gov.

[5] Cornell University, Pesticide Management Education Program (PMEP) http://pmep.cce.cornell.edu. 